latter part of that time. He joined the University of Michigan in 1984.

Gibala has served on numerous advisory committees and participated in various professional societies. He served as councillor on the MRS Executive Committee in 1996. In 1988, he co-organized a symposium on science and technology of refractory metals at the MRS Spring Meeting. $\mathrm{He}$ is one of the meeting chairs for the 1998 MRS Spring Meeting.

\section{Alan I. Taub \\ Councillor}

Alan I. Taub is manager of the Materials Science Department at Ford's Research
Laboratory. His research interests have included studies in flow and structural relaxation in amorphous alloys, mechanical properties of rapidly solidified nickel-base alloys with emphasis on improved ductility in intermetallic compounds for aircraft engine applications, and processing of superconducting materials for medical magnets. He currently manages research activities on advanced automobile body, chassis, and powertrain materials.

Taub received his $\mathrm{ScB}$ degree in materials engineering from Brown University in 1976 and his PhD degree in applied physics from Harvard University in 1979. From there he worked with General
Electric's Corporate Research and Development Center until 1993. He most recently managed the Materials Properties and Processes Laboratory at GE before joining Ford.

Since joining MRS, Taub has co-organized two symposia on amorphous alloys and high-temperature materials and two on manufacturing, he has co-chaired the 1993 MRS Fall Meeting, and is currently leading the MRS Headquarters Building Task Force. Taub served as councillor on the MRS Executive Committee in 1996. $\mathrm{He}$ is also a member of the External Affairs and Public Affairs Committees.

MIRIS

\title{
Journal of Materials Research: Status Report 1996
}

The Journal of Materials Research (JMR) continues as a primary archival, cross-disciplinary journal in materials science and technology. It remains in the top $5 \%$ of all journals in materials in terms of high citations/paper and low subscription cost/ page. It is supported by an unusually dedicated group of editors.

The increasingly faster pace in materials has led to an increased need for rapid publication. $J M R$ communications are now handled by two special editors, Patrick Gallagher and Robert Frankenthal. We particularly invite submission of new, highquality work for consideration as communications.

By its nature, materials constantly moves in new directions. In an effort to present perspectives on emerging areas and updates on continuing, exciting areas, we have from time to time published "Focus Issues" in which a substantial part of one JMR issue is devoted to papers on a common theme, gathered together by a focus issue editor. Two past issues were on "Green Materials," edited by Julian Szekely, and "Synthesis and Processing," edited by Peter Esherick. Future focus issues will include "Green Materials II," "Superconductivity-Ten Years of Progress," and "Photovoltaics." Paul Siffert has recently agreed to act as Focus Issue Editor.

Under the guidance of two review editors, Lynn Boatner and Harry Leamy, JMR continues to commission review articles on appropriate topics. Our goal has been at least six high quality reviews per year and we are approaching that level. Review editors invite suggestions for reviews.

Finally, $J M R$ is entering the electronic age. At the 1996 MRS Fall meeting the first CD product for Journal of Materials Research was demonstrated. IMR Volume 11 (January-December 1996) plus the entire IMR cumulative indexes (11 years) have been put onto a CD-ROM. The software used is Adobe Acrobat Reader" which is operational on Macintosh Windows, and Unix formats. The cumulative indexes include full abstracts. All articles in Volume 11 as well as the indexes are searchable by title, author, material, key word, subject, date of publication, or word stemming.

ROBERT A. LAUDISE IMR Editor-in-Chief

\section{ND INDUSTRIAL ENERGY EFFICIENCY SYMPOSIUM \& EXPO}

\section{FEBRUARY 25-27, 1997 Hyatt Regency Crystal City • Alexandria, Virginia}

Sponsored by the U.S. Department of Energy and the Office of Industrial Technologies

This two-day conference will spotlight the public-private research and development partnerships that are in place in seven key process industries: aluminum, chemicals, forest products, glass, metal casting, petroleum, refining, and steel.

Find out how these industries will be gaining a competitive edge in rapidly changing global markets. See how the industries of the future will meet the energy, environmental, and economic challenges of tomorrow. Learn how collaborative R\&D addresses industry needs and accelerates the development of crosscutting technologies such as advanced turbines, textiles, advanced materials and composites, forging, heat treating and welding.

For more information, contact Conference Services, Energetics, Inc., 7164 Gateway Drive, Columbia, MD 21043; fax 301-621-3329; e-mail OIT.EXPO97@HQ.DOE.GOV.

\section{International Conference on Advanced Materials (ICAM'97) and European Materials Research Society (E-MRS'97) \\ Strasbourg, France June 16-20, 1997 \\ Deadline for Abstract Submission: February 1, 1997 \\ For more information, contact P. Siffert, Conference Secretariat, E-MRS 1997 Spring Meeting, BP 20, 67037 Strasbourg Cedex 2, France; phone 33-03-88-10-65-43; fax 33-03-88-10-62-93; e-mail EMRS@FRCPNI 1.IN2P3.FR.}

